\title{
Stratigraphic framework of the thrust geometry and structural inversion in the southeastern Pyrenees : La Garrotxa area
}

\author{
Le contrôle stratigraphique \\ de la géométrie des chevauchements \\ et inversion tectonique \\ dans les Pyrénées orientales: \\ La Garrotxa
}

by Albert MARTINEZ*, Jaume VERGÉS*, Eduard CLAVELL** and John KENNEDY**

\begin{abstract}
The structure of la Garrotxa area within the Cadí unit (south-eastern l'yrenees) consists of a set of duplexes at different scales which repeat the different rarbonatie litho-units of the Lower and Viddle Eorene. These duplexes are folded by antiformal stacks structures with basement rocks in their eores. The north boundary of these antiformal stacks represents an inversion of pre-existent extensional faults which formed hall-yraben geometries. The basement rocks involved in the structure represent short-cuts formed in the footwall of the extensional faults. All thrusts of La Garrotxa area branch with the upper Garrotxa thrust. The more complex structure of La Garrotxa area than the adjacent areas within the Cadi unit, is due to the initial complex synsedimentary geometry of the sedimentary pile.

The Cadi unit overlies the Serrat unit with a hangingwall ramp geometry. This unit was deduced from the Serrat-1 well. drilled in 1987. The Serrat unit is made up of a Middle Eocene evaporitic sequence, with alternating shales and anhydrites and a 100 meters thick salt laver close to the top. The total thickness of this evaporitic Beuda sequence is 1000 meters. The Beuda sequence clearly controlled the thrust geometry of the younger thrusts.
\end{abstract}

Key-words : Pyrenees, Thrust, Inversion tecenic. Eocene evaporites. Short-rut.
RÉSLMÉ. - La structure de La Garrotxa qui fait partie de la nappe du Cadi (dans les Pyrénées orientales) est formée par une série de "duplex " de différentes échelles lesquels répètent les différentes unités litostratigraphiques de l'Eocène inférieur et moyen. Ces "duplex " sont déformés par des anticlinaux de nappes (antiformal stacks) de direction E-W aver roches du socle au cour. Les flancs $N$ de ces bombements représente l'inversion de failles extensives antérieures ayant formé des demi-grabens. Les divers chevauchements de La Garrotxa se branchent sur le chevauchement supérieur de La Garrotxa. Cette structure, plus complexe dans la zone de La Garrotxa que dans les régions voisines de la nappe du Cadi, est due à la complexité initiale de la série sédimentaire.

La nappe du Cadí repose sur la nappe du Serrat selon une géonétrie de rampe de toit. Cette nappe fut découverte par le forage en 1987 du puits du Serrat-1. La nappe du Serrat est constituce par une alternance de marnes et d'anhydrites avec $100 \mathrm{~m}$ de sel près du sommet. L'épaisseur totale de rette série évaporitique (séquence de Beuda) est supérieure à $1000 \mathrm{~m}$. La série évaporitique de Beuda contrôle la géométrie des chevauchements plus modernes.

Mots-clés : Pyrénées, Chevauchement, Inversion tectonique, Evaporites eocìnes, Raccourcissement.

* Enamorats. 132, 2, 1a. 08026 Barcelona.

* I nion Texas España. Ine. Miguel Angel, 11, 3. 28010 Madrid. 


\section{IVTROD) CTIO)}

There are many examples of the tertonic regime controlling the sedimentary evolution of the basins in rompressionat and tensional terains. The opposite observations. where the sedimentation rontrols tectonic evolution. is very rlifficult to observe. but everything points to the lacet that it occurred in a thin-skinned thrust system. especially in the most externat zones (Thomas, 1988). Such control roukl be "xplained by the changes in lateral and vertical lithofacies. as well as by changes in thickness. thereby implying diflerent rheological properties of the rocks involverl in thrust sistems.

In eastern Pyrenees. I a Garrotsa zone - Cadí thrust sheet - (Figs. I and 2). with a romplex geometry, is a very good place to obseme the relationship between tectonies and sedimentation.

This paper demonstrates the relationship between litholowieal rhange's in Lower and Videlle Locene sediments and thrust geometry of the Eastern Pyrenees (particularly in La (Garrotva areal).

\section{FACIES IDISTRIBLTION IN THE EOCFNE}

In a cross-section, from I a Garrotxa (southern Pyrenean thrust sheets) to the south, across the foreland basin (Ebro Basin), the sedimentary sucression consists of Garumnian beds (Tremp formation. Vey et al.. 1968) lying unconformably on the basement and surceeded by a Lower to Middle Eocene section. This Eocene sedimentary succession has been divided into depositional sequences (Fig. 2) which are particularly related to the allochthonous section of the Cadi thrust sheet (Puigdefâbregas et al.. 1986). Overlying the Garumnian, the Lower Eocene sequence comprises shelf Alveolina limestones recognized as the Cadí formation (Mey et al. 1968) and caleareous shales of the Sagnari formation (Cich, 1969) which were deposited in an open marine environment. The Sagnari formation crops out in the Cadi thrust sheet and rhanges laterally to Cadi limestones eastwards in La Garrotxa area. The Sagnari and Cadí formations are coeval (Fig. 3). Wells drilled during petroleum exploration in the foreland basin found a similar limestone section known as the Orpí formation (Ferrer.

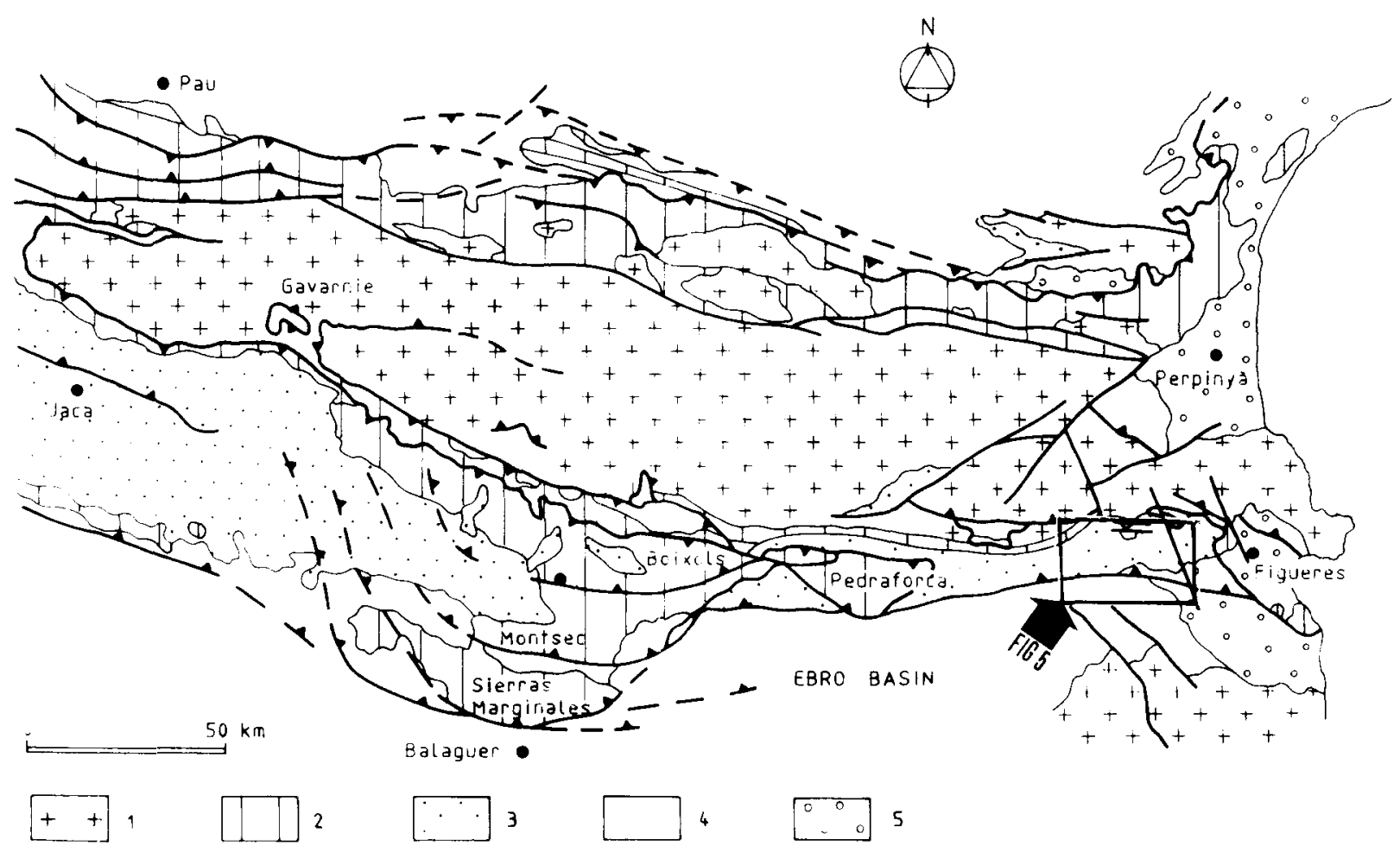

Fil; 1. - Structural skelch of the central and eastern Pyrenees and location of figure 5.

1) Ilercynian basement: 2) Mesozoir: 3) Allocthonous Paleogene: 4) Foreland Paleogene; 5) Veogene.

Fili. 1. - Schéma des Pyrénées centrales et orientales et localisation de la figure 5.

1) Sorte herrymien: 2) Wésozö̈que: 3) Palégè̀ne allortones f) Paléogène d'avant-pays; 5) Véogène. 


\begin{tabular}{|c|c|c|}
\hline AGES & SEQUENCES & FORMATIONS \\
\hline OLIGOCENE & SOLSONA & SOLSONA (alluvial and fluwial) \\
\hline & CARDONA & CARDONA (marine evaporites) \\
\hline BARTONIAN & MILANY & MILANY (delta front) \\
\hline \multirow[t]{2}{*}{ LUTETIAN } & BELLMUNT & $\begin{array}{l}\text { BELLMUNT (alluwial and fluvial) } \\
\text { COUBET (transitionai) } \\
\text { BARCONS (transitional, Ebro Basin) }\end{array}$ \\
\hline & BEUDA & BEUDA (evaporites) \\
\hline \multirow[t]{2}{*}{ CUISIAN } & CAMPDEVANOL & $\begin{array}{l}\text { VALLFOGONA (turbidites and evaporites) } \\
\text { CAMPDEVANOL (turbidites) }\end{array}$ \\
\hline & ARMANCIES & ARMANCIES (slope). PENYA (carbonate shelf) \\
\hline \multirow[b]{2}{*}{ ILERDIAN } & CORONES & CORONES (outer platform) \\
\hline & CADI & CADI (shelf), SAGNAFI (ope \\
\hline
\end{tabular}

Fic: 2. - Depositional sequences of the southeastern Pyrenees and Ebro basin (modified from Puigdefàbregas et al., 1986).

Fic. 2. - Séquences sédimentaires des Pyrénées Sud-orientales et de l'avant-pays de l'Ebro (modifiée de Puigdefabregas et al., 1986).
1971), which is equivalent to the Cadí formation and represents carbonate deposition upon the southern shelf of the Eocene basin. Overlying the Cadí limestones, the Corones sequence (Late Ilerdian to Lower Cuisian) is found. The lagoonar and deltaic facies of this sequence, in la Garrotxa area, is the same as that found all along the outerop of the Cadi thrust sheet. The Armancies sequence shows a similar change of facies as that found in the Cadi sequence. la Garrotxa area contains shelf limestones assigned to La Penya formation (Estévez, 1973) and westwards, calcareous shales of the Armàncies formation (Cich, 1969), representing deposition on the continental slope and deeper marine environments, both with the same age. In the foreland basin, the equivalent sediments consist of carbonate shelf deposits from the Perafita formation (Ferrer, 1971) overlain by red beds of the Pontils Group. Above the Armàncies sequence the Campdevànol sequence is distinguished as a sequence of terrigenous flysch. The upper part of this sequence is made up of a thick section of evaporites and shales that represent the basin fill during the Early lutetian. This evaporitic succession is assigned to the Beuda

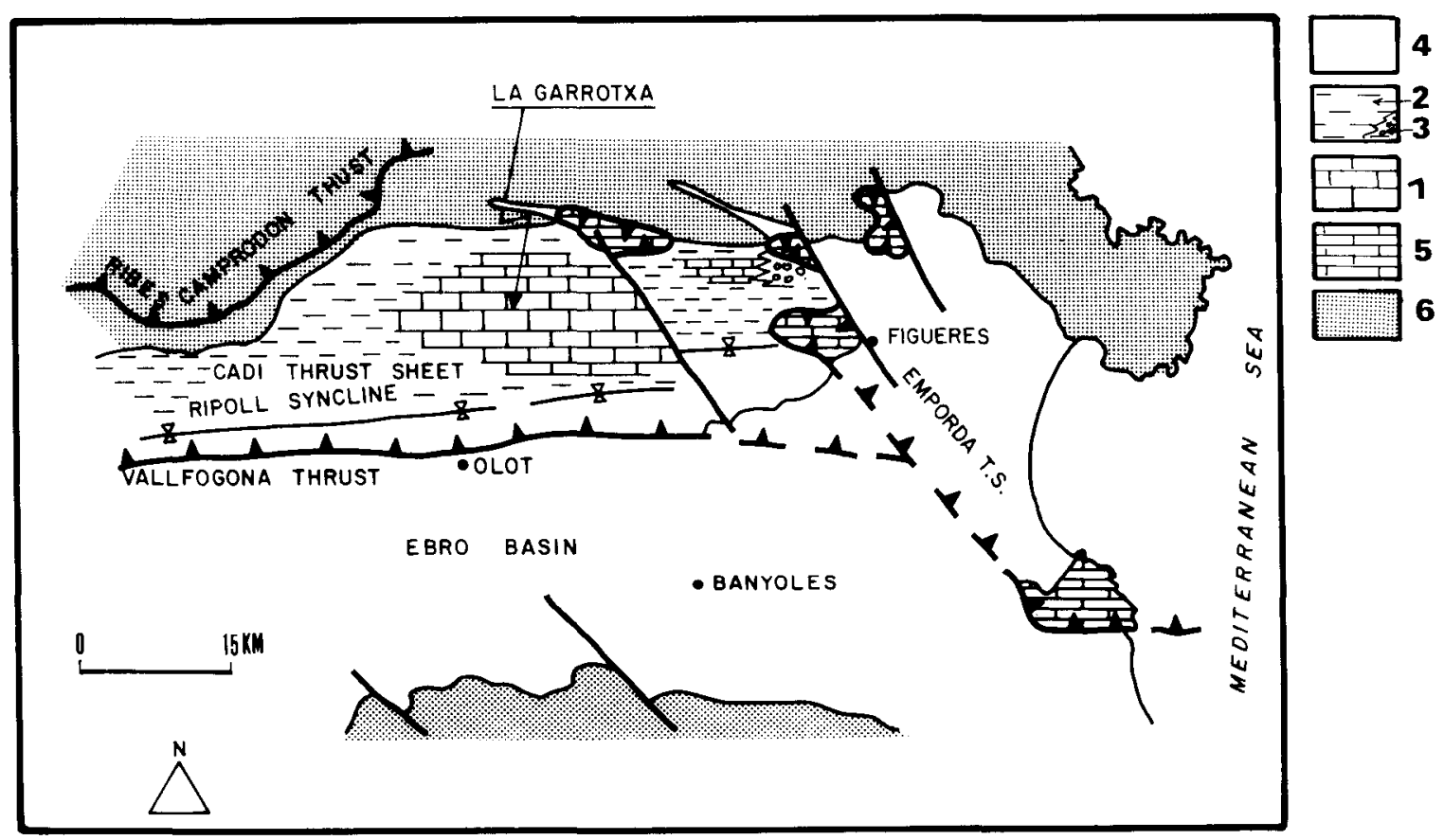

Fic. 3. - Facies distribution of the Lower Eocene.

La Garrotxa area rontains (arbonate shelf sediments (Cadí formation). To the north and south of La Garrotxa area there are open marine shelf sediments (Sagnari formation). The foreland basin has carbonate shelf sediments (Orpí formation), revealed from sections drilled in exploratory wells. All these formations have the same age.

1. Carbonate shelf (Ypresian): 2. Open marine (Ypresian); 3. Conglomerates (Ypresian); 4. Veogene; 5. Mesozoic units; 6. Paleozoic units.

\section{Fik, 3. - Distribution de faciès de l'Eocène inférieur.}

la sédimentation dans la Garrotxa est de type plateforme carbonatée (formation de Cadi). lers le vord affleurent des marnes bassinales (formation de Sagnari). Dans lacant-pays de lWbro. les sondages ont recoupé les calcaires de la formation d'Orpí, qui représenient la plateforme Sud de même âge. 
formation which is poorly known in outcrop but in subsurfice. Serrat-1 well, is known to reach about 1000 meters of alternating shates and anhydrites with 100 meters of salt in the uppere part. The isopach map of the Beuda formation (Fig. 1) shows its depocentre. This lies parallel to the depecentre of the underlying sequences, but shifted more to the south, indicating that with time the Eocene depocentre migraterl southwards (Puigdefàbregas et al., 1986; lergés \& Martinez. 1988). The Beuda sequenee outeropping in the Catrli thrust sheet, contains about 100 meters of anhydrites representing deposition in a shallow marine environment (Orti et al. 1988). This sequence. in the foreland directly overlies the Perafita formation of the Amancies sequence. The same vertical relationship is apparent in La Carrotxa where the Camprevànol formation is absent and the carbonate shelf deposits of La Penya formation are coeval with the typical Armancies sucression of the Cadi houst sheet.

The nevt overlying sequence eomprises the Bellmunt and Milans sequences which were deposited synchronousls with the emplacement of the late thrust sheets and, therefore are not relevant to the subject of this paper.

\section{STRLCTLRE}

\section{La Garrotxa area}

La Garrotxa lies within the eastern zone of the Cadi thrust sheet (Fig. 5). It is limited to the east by the Albanyà Fault. The western limit is traced by the line of the upper Garrotxa thrust. The east-west trending Ripoll syncline (Fig. 5), lies to the south of La Garrotxa structural area and constitutes the main structural leature of the Cadi thrust sheet westwards (Muñoz et al., 1986). The structural complex of La Garrotxa consists of a set of duplexes which repeat the carbonate litho-units of Cadí, Corones and La Penya formations. The hangingwalls and footwalls of the thrust slices are coincidental with the upper and lower sedimentary limits of each formation. The pilling of several duplexes forms an antiformal stack. Several of these elongated east-west structures are visible in the map (Fig. 5).

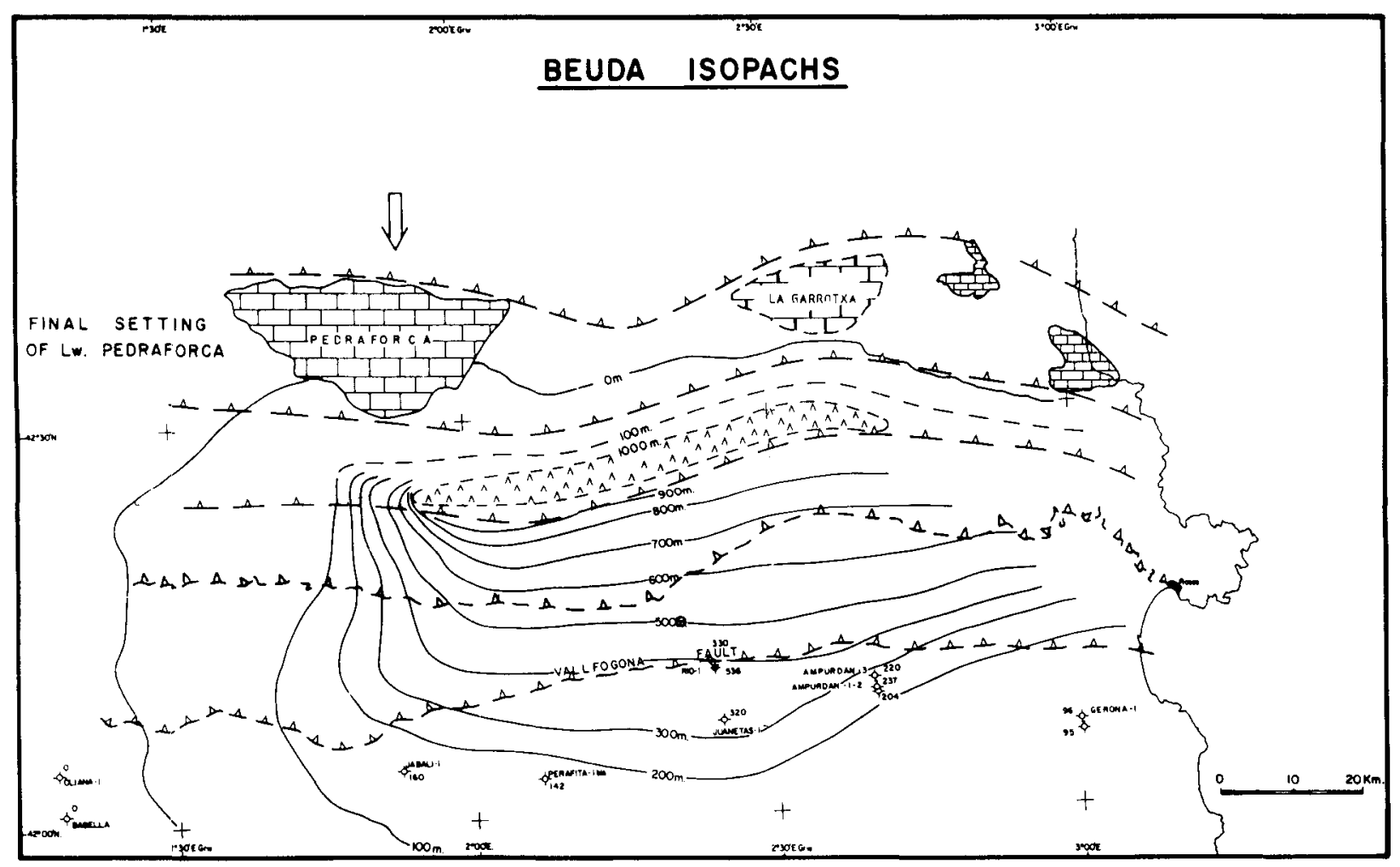

Fik. 1. - Isoparh map of the Beuda sequence. The depocentre of this sequence was found by the Serrat-1 which had 1 o00 metres of evaporitic sediments.

Fì. 1. - Carte en isopaques de la séquence de Beuda. Le dépocentre de la séquence est recoupé par le sondage Serrat-I. L'épaisseur des évaporites est supérieur à 1000 mètres. 


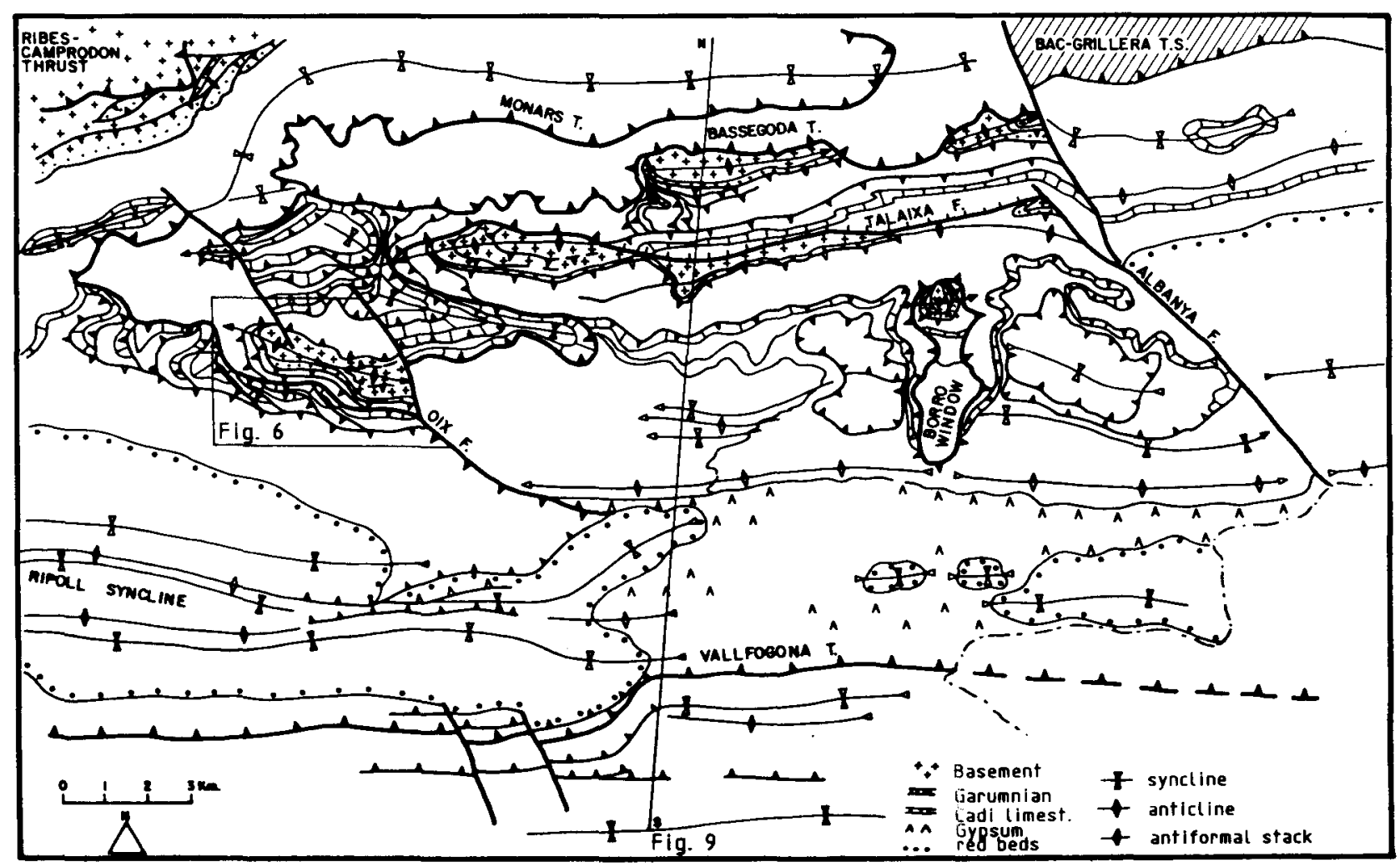

Fit, 5. - Tectonic sketch of La Garrotxa area (Cadí thrust sheet).

The structure consists of a series of duplexes in different scales. The antiformal stack structures have an E-W trending involving basement rocks in their core. The different thrusts join in the upper Garrotxa thrust. The structural differences between La Garrotxa and westermost zones is controlled by the sedimentary lacies rhanges. The Borro window lies on a X-S axis. This axis is located at the change in dip of the structures. East of this axis the structures dip to the east and in the west, westwards. Location of the map in fig. 6 and cross-section of fig. 9.

\section{Fic; ,. - Schéma structural de La Garrotxa (Nappe du Cadi).}

Il est caructérisf par la coexistence de "duplex" de différentes échelles et par un anticlinal de nappes de dirention E-W. Dans la partie centrale de cess structures affleurent des roches du socle. Tous les chevauchements se rencontrent dans le chevauchement supérieur de La Garrotxa. La ligne V.S de changement de linclinaison des structures est située sur la transversale de la fenêtre du Borro. A l'Est de cette ligne, les structures plongent vers lWst. et à lOuest vers lOuest. La localisation de la carte de la fig. 6 at de la trace de la coupe de la fig. 9 est indiquée.

Basement rocks are involved in the core of these structures with the roof thrust of the different basement horses located in the Garumnian shales. It is very difficult to recognize the importance of the role of every thrust in the complex. This is due to the minor sedimentological differences between the lithological units of each thrust sheet and because it is difficult to continue these thrusts with flat geometry across shales which are interbedded between two calcareous units. The geological map shows that the leading branch lines of all the different duplexes branch to the upper Garrotxa thrust.

The detailed map of these culminations (Fig. 6) shows an antiformal stack with a core formed by Paleozoic metamorphic rocks or granite with unconformably overlying Garumnian shales. The Garumnian is sometimes repeated within the thrust slices of the basement.
One of the characteristics of the antiformal stack structures is the asymmetry between the northern and southern flanks (Fig. 7). To the south, on top of the Garumnian, there is a set of horses, constituted by limestones of the Cadí formation, dipping to the south. On the northern side sediments coeval with those of the southern flank, but in open marine facies, overlie the basement. The contact between these sediments and the basement lies along structural inversion where thin tectonically laminated red shales of the Garumnian sometimes crop out. The northernmost culmination, at Sant Aniol (Fig. 9), shows the southern flank comprised of Cadi limestones thrusted by the Bassegoda thrust. The hangingwall of the Bassegoda thrust is constituted by transitional facies between the Cadi and the Sagnari formations, consisting of alternations of limestones and calcareous shales. These are, in turn, overthrusted by 


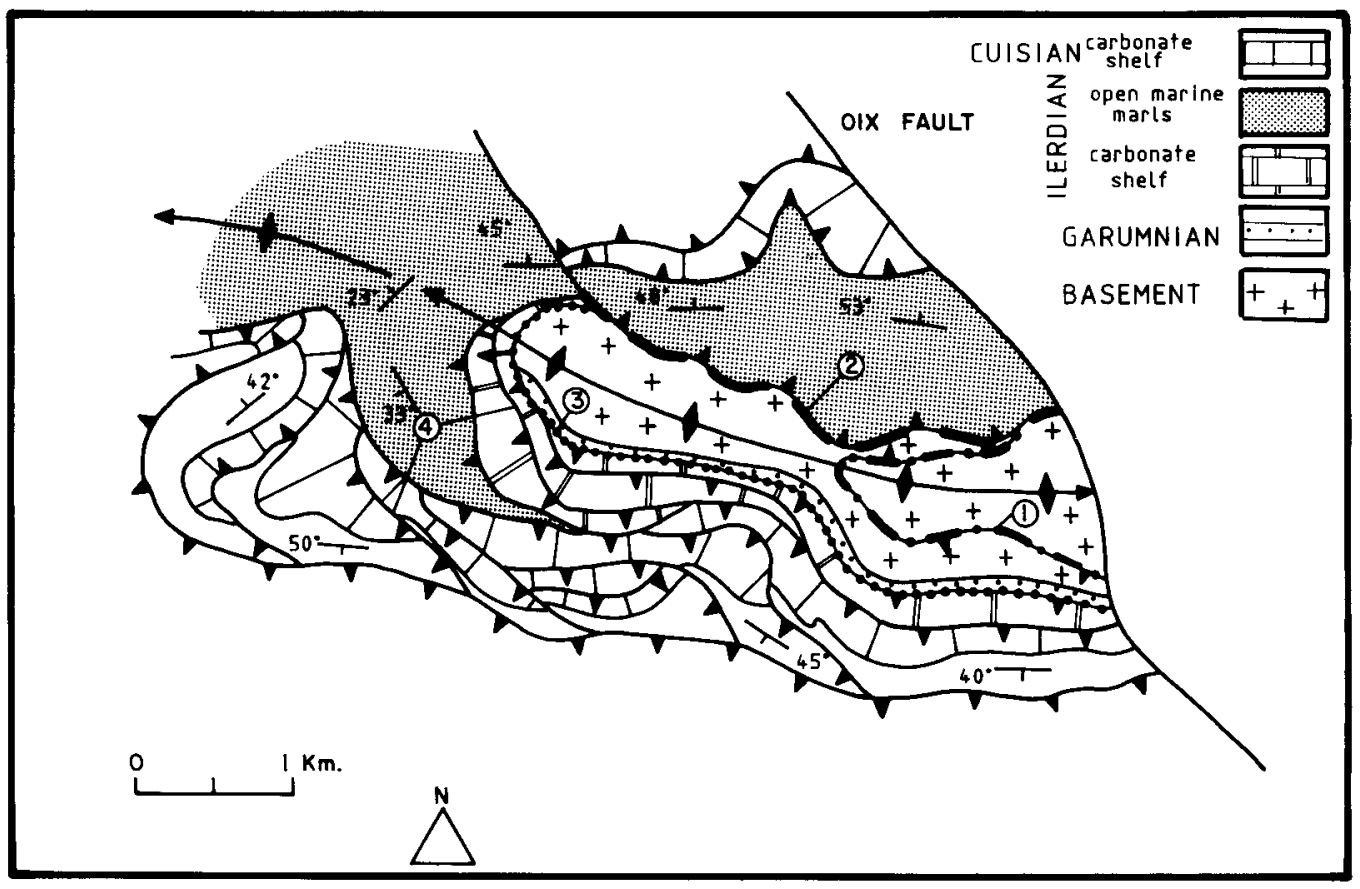

FIC. 6. - Struetural sketch of the Montmajor antiformal stack.

Note the presence of basement involved in the structure and the dissymmetry of both flanks, limestones to the south and shales to the north, and the northern subsiractive contact.

Fì. 6. - Schéma structural de l'anticlinal de nappes du Montmajor.

II faut noter la présence de calcaires de plateforme dans le flanc Sud et de marnes plus profondes dans le flanc Nord. On peut observer quatre chévauchements différents dépendant des niveaux stratigraphiques affectées. Les chevauchements sont numérotés de la même manière sur les figs. 7 et 8.

$\mathbf{S}$

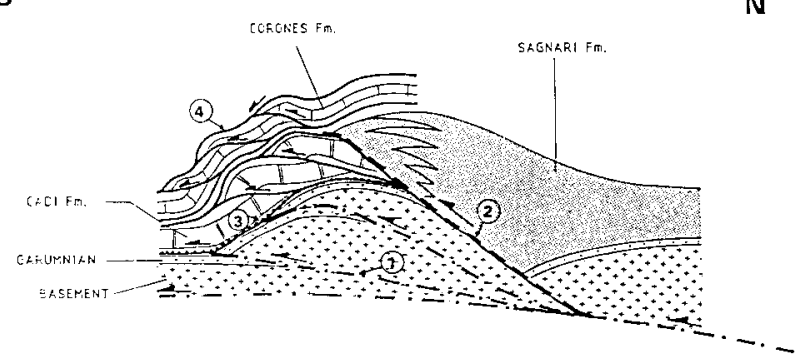

Fic. $i$. - Schematic cross-section of the Montmajor antiformal stack.

Four types of thrust could be observed : 1) thrust involving basement rocks and Garumnian cover; 2) pre-existing extensional fault inverted as a thrust. This fault joins open marine facies on top of carbonate shelf deposits of the same age; 3) floor thrust of the duplex system and 4) duplexes at every limestone level.

Fi木. 7. - Coupe schématique de l'anticlinal de nappes du Montmajor.

On peut y observer 4 types de chevauchements : I) chevauchemeni affectant le socle hercynien et sa couverture garumnienne; 2) chevauchement reprenant des failles normales préxistantes; 3) décollement inférieur des différents "duplex"et 4) structure en "duplex" dans chaque niveau calcaire. $\mathbf{s}$

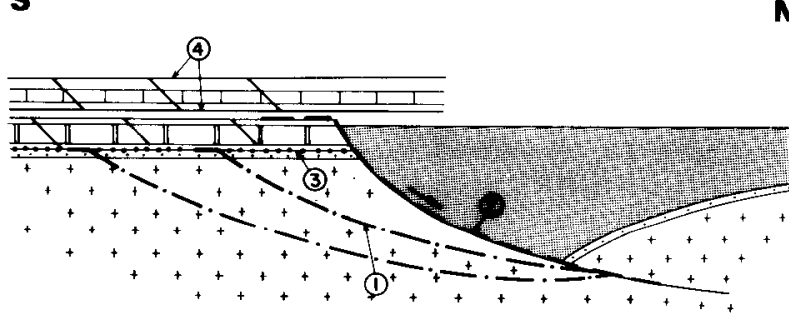

Fici, 8. - Schematic restored cross-section of the Montmajor antiformal stack.

It shows an extensional fault that originates a half-graben geometry which is then reactivated into a thrust. The southern migration of the thrust gaves rise to a short-cut of basement rocks (2), located in the footwall of the extensional fault. The roof thrust (3) of the duplex is located in the Garumnian red shales. A series of duplexes (4) lies at the top.

FIG. 8. - Coupe schématique restituée de la géométrie initiale avant les chevauchements de la Fig. 7.

Une ancienne géométrie en demi-graben est inversée et au mur de la faille se forment des "short-cuts " de socle hercynien. 
the coeval calcareous shales of the Sagnari formation upon the Monars thrust (Fig. 9). The calcareous shales of the Sagnari formation are very well developed towards the west where they constitute the Cadí sequence in the central part of the Ripoll syncline (Fig. 5).

La Carrotxa zone shows a change in plunge of the structures. The axis of this change of plunge occurs in the Borro river section - Borro tectonic window - (Fig. 5). From this line to the east there is an easterly plunge of structures, and to the west of the line a west plunge is observable. This type of geometry is related to the northsouth culmination of the autochthonous basement observed in the subsurface (Clavell et al., 1988).

\section{Antiformal stack and thrusting geometry}

The restored cross-section of an antiformal stack (Fig. 8) shows the relationship between the thrust system and the pre-existing geometry. This reconstruction explains the main chararteristies of the antiformal stark: particularly the presence of basement involved in its core. the change of sedimentary facies between the northern and the southern flanks and the structural inversion of the northern flank.

The propagation of the sole thrust of the Cadi unit reactivated a system of older extensional faults present in the northern flank of the antiformal stack. The effect of the movement was to thrust the offshore facies, deposited in a half graben (on the footwall of fault). upon the carbonate shelf (deposited on the hangingwall fault). The reartivation does not seem to be very important because the major portion of these older extensional faulis remains unreversed. Geological mapping shows all the pertinent strurtures as a thrusts, except the Talaixi fault (Fig. 5) which is a reverse fault to the west and becomes a normal fault eastwards. The movement of the thrust system to the south cuts basement rocks of the half graben footwall to form a gently dipping short cut (Gillcrist et al.. 1987) which is bounded by an upper thrust located within Carumnian red

\section{$\underline{S}$}
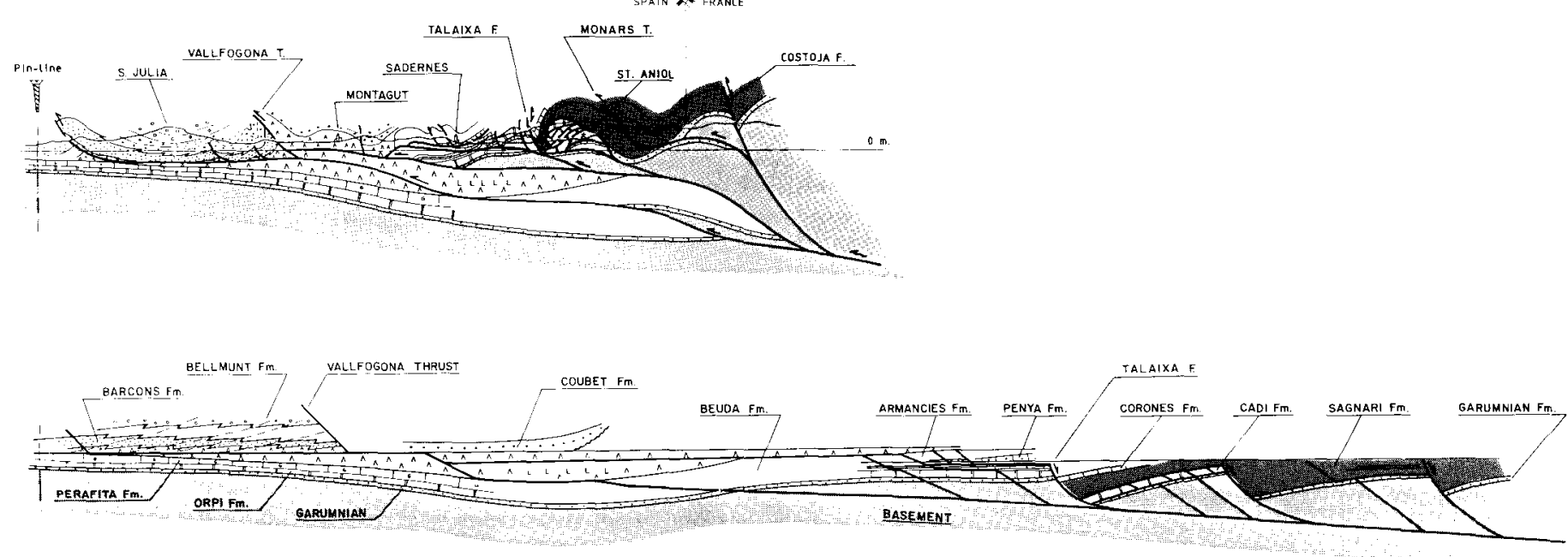

$2=\underbrace{3 n m} \mathrm{~V}=\mathrm{H}$

\section{Fili, 9. - Balanced and restored cross-section N-S across La Garrotxa area.}

In the balanced cross-section. to the north, an antiformal stack with basement rocks may be observed. The central zone presents a stack of thrust sheets with thick lower Eocene sediments - Cadi and Serrat thrust sheets - The Vallfogona thrust is the sole thrust of the thrust system. The foreland shows the relation between the thrust and the synorogenic sediments proving a piggy-back propagation. Restored cross-section N-S : During the Lower Eocene the northern part of the basin presented a half-graben geometry. This structure was synchronous with the compressional tectonics in the basin. The cross-sertion shows the migration of the depocentres towards the south. synchronous to the thrust system.

\section{Flc: 9. - Coupe équilibrée et restituée $\mathrm{N}-\mathrm{S}$ à travers de La Garrotxa.}

lers le I, sur la coupe tectonique actuelle, on peut observer une culmination comportant des terrains appartenant au socle hercynien. La partie centrale est représentée par un empilement de nappes, aver une série éocène très épaisse (unités du Cadi et du Serrat). Le chevauchement de lallfogona est le plus inférieur du système de chevauchements. Les relations entre structures et sédiments synorogéniques de lavant-pays montre une progression conforme. Dans la coupe restituée on peut reconstituer une géométrie en demi-grabén pendant lEocène inférieur synchrone des chevauchements et la migration des différents dépocentres vers le sud. 
$\underline{\mathrm{S}}$

VALLFOGONA T.

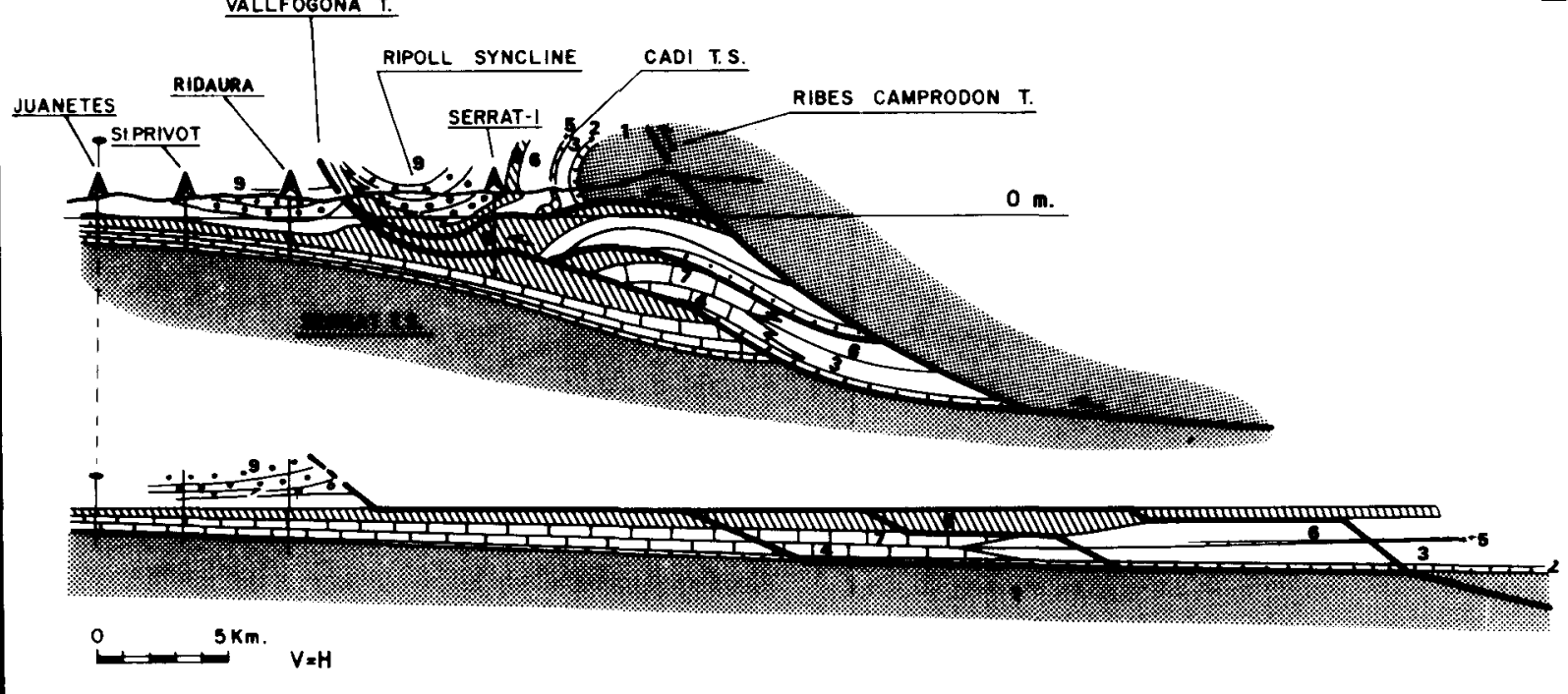

Fil: 10. - Balanced and restored cross-section N-S across the Serrat-I well Iransverse.

The Lower Eocene of the Cadi unit constitutes a hangingwall ramp. Transitional and continental Middle Eocene sediments (Bellmunt sequence) lie unconformably on top and are prograding towards the south. These continental red beds show a synchronicity with the development of the northern antiformal stack basement. The evaporites and salts of the Beuda sequence form an excellent decollement level. 1) Basement; 2) Garumnian; 3) Sagnari formation (open marine: marls): 4) Cadí formation (carbonate shelf); 5) Corones formation; 6) Armàncies and Campdevànol formations; 7) Perafita formation: 8) Beuda formation (evaporites); 9) Bellmunt formation (continental).

Fli. 10. - Coupe équilibrée et restituée passant par le sondage Serrat-l.

Less sédiments de lWocène inférieur de la nappe du Cadi forment une rampe de toit. Les sédiments de transition et continentaux de la séquence de Bellmunt se trouvent en discordance et progradent vers le Sud pendant la formation de l'antiforme a cour hercynien plus au Nord. Les évaporites de la séquence de Beuda constituent un niveau privilégié de décollement.

shales. On top of this system, the Cadí and Corones formations are involved in duplex structures.

\section{Balanced cross-sections}

The balanced cross-section of Ripoll (Fig. 10) lies to the west of the cross-section of La Garrotxa. The Serrat-1 well is close to the former. Cross-section of Ripoll, shows the same structural style as la Garrotxa one, but it is simpler. The cross-section extends southwards through three exploratory wells.

The Sagnari formation. to the north of the Ripoll syncline, exhibits an internal structure dominated by folds and axial plane rleavage (Muñoz, 1985). The same type of mesostructures are found in the Sagnari formation on the northern side of La Garrotxa.
The Serrat-1 well shows that the base of the Cadí thrust sheet is present at a shallow depth and located on top of another thrust sheet comprised of evaporites and shales of the Beuda formation belonging to the Beuda sequence. The cross-section shows that all sequences of the Lower Eocene (Cadí, Corones, Armàncies and Campdevànol sequences) located in the hangingwall are cut off at a high oblique angle by the sole thrust. This sole thrust of the Cadí unit joins the Vallfogona thrust to the south where the latter ramps up from its flat on top of the Beuda evaporitic sequence.

On top of the evaporites, deposited in the Cadi unit, the Bellmunt sequence comprises the transitional sediments of the Coubet formation and the overlying continental red beds of the Bellmunt formation. The sediments of this Bellmunt sequence lie unconformably on top of the previous sequence in a downlap configuration towards the south.

The Serrat unit consists of evaporitic sediments of the Beuda sequence and the continuation of the underlying 
Lower Eocene sequences cut by the hangingwall of the Cadi thrust. The Vallfogona thrust limits the Serrat thrust sheet. This thrust has a flat developed upon the evaporites of the Beuda sequence of the autochthonous unit. These evaporites are know from wells drilled in the foreland basin (Fig. 10).

The out-of-sequence Ribes-Camprodon thrust (Muñoz, 1985) would appear to be the northern limit of the Serrat and Cadí units. The synorogenic sediments (Fig. 9), coeval with the propagation of the thrust system (Bellmunt and Milany sequences) show progressive unconformities fossilizing the thrust system along its southern margin.

\section{DISCUSSION AND CONCLUSIONS}

The balanced cross-sections across the south-eastern Pyrenees (La Garrotxa and Ripoll) show a similar regional structure but are different in detail. These differences mainly concern the internal structure of the Cadí thrust sheet and are related to the previous deposition of the sedimentary pile.

The La Garrotxa area, with a more complex structure, was dominated in early times by extensional geometries in the south, coeval with compressional structures (thrusting) in the north, as has been proved by Pujadas et al. (1989). These extensional half-graben geometries (Fig. 9) controlled the sediment deposition with open marine marls on the hangingwall and carbonate limestones on the footwall of the faults. Westwards (Ripoll cross-section), only open marine marls were deposited, during the same period. The halfgraben geometry must have developed through lithospheric flexure originated from the emplacement of the Mesozoic units: the Pedraforca unit westwards and mainly the Empordà unit eastwards. This intermediate zone between the areas occupied by the Pedraforca and Empordà units, coincides with a high basement which was active from the Uppermost Cretaceous (Clavell et al., 1988). The readjustment of the half-graben geometries by the thrust system gave rise to a tectonic inversion. In spite of this structural inversion several faults, such as the Talaixà fault, show a substrartive contact (Fig. 9).

Apart from the tectonic structures, the different stratigraphic frameworks in the La Garrotxa and Ripoll areas induce a different thrusting geometry. Open marine marls developed folds and axial plane cleavage in the Ripoll area. In the I a Garrotxa area the alternation of limestone levels and thin marls, formed several duplex systems, with the upper and lower thrusts of each system located in the thin marls at the top and bottom of the limestone levels.

The Cadí unit in both cross-sections, shows a hangingwall ramp geometry, with a very high cut-off angle for the
Lower Eocene sediments, mainly in the Ripoll one. The Cadí thrust sheet overlies a thick evaporitic series of anhydrites and salt, which constitutes a lower and younger thrust sheet called the Serrat thrust sheet. The Vallfogona thrust, which is the lower thrust of the Serrat thrust sheet, represents the sole thrust of the southeastern Pyrenean thrust system (Muñoz et al., 1986). Southwards of the Vallfogona thrust, in the foreland, a set of thrusts can be observed (Fig. 9).

The upper part of the Beuda formation and the Coubet and Bellmunt formations, located in the Ripoll syncline (numbers 8 and 9 in Fig. 10) could be syn- and post- Cadí thrust sheet emplacement. In agreement with this, in the La Garrotxa area, large gypsum breccias outcrop in a narrow area along the front of the Cadí thrust sheet (north of Montagut in Fig. 9), demonstrating the timing of the motion of the thrust sheet. In the footwall of the Vallfogona thrust, older sediments were affected by thrusts and younger ones were affected by a synorogenic syncline with several angular unconformities. Relationships between the thrusts and related sediments from the Cadí unit to the more southwards foreland structure show a piggy back thrusting propagation sequence.

The La Garrotxa and Ripoll cross-sections present a more detailed structure of the southeastern Pyrenees and show an increase in the total shortening of this part of the chain.

\section{REFERENCES}

Clavell E., Martínez A. \& Vergés J. (1988). - Morfologia del basament del Pirineu oriental: evolució i relació amb els mantells de corriment. Acta Geol. Hispànica, 23 (2), p. $129-140$.

Estévez A. (1973). - La vertiente meridional del Pirineo Catalán al norte del curso medio del río Fluvià. Publ. Univ. de Granada, p. 1-519.

FERRER J. (1971). - Le Paléocène et l'Eocène des Cordillerès Cotières de la Catalogne (Espagne). Mém. Suiss. Paleont., 90, p. 1-70.

Gich M. (1969). - Las unidades litoestratigráficas del Eoceno pre-pirenaico del Ripollés oriental (prov. de Gerona y Barcelona). Acta Geol. Hispànica, 4 (1), p. 5-8.

Gillchrist R., Coward M. \& Mugnier J.L. (1987). - Structural inversion: examples from the Alpine foreland and the French Alps. Geodinamica Acta, 1 (1), p. 5-34.

Mey P.H.W., Nagtegaal P.J.C., Roberti K.J. \& Hartevelt J.J.A. (1968). - Lithostratigraphic subdivision of post-hercynian deposits in the south-central Pyrenees, Spain. Leidse Geol. Mededelingen, 41, p. 221-228.

MuÑOZ J.A. (1985). - Estructura alpina i herciniana a la vora sud de la zona axial del Pirineu oriental. Tesi doctoral. Univ. de Barcelona, p. 1-305.

Muñoz J.A., Martinez A. \& Vergés J. (1986). - Thrust sequences in the eastern Spanish Pyrenees. J. Struct. Geol., $8(3 / 4)$, p. $399-405$. 
Ortí F., Busquets P., Rosela L., Taberner C., Utrilla R. \& QuADRAS M. (1988). - La fase evaporítica del Eoceno medio (Luteciense) en la cuenca surpirenaica catalana. Nuevas aportaciones. Revista Inv. Geol., 40-41, (in press).

Pligidfáabregas C., Muñoz J.A. \& Marzo M. (1986). - Thrust belt development in the Eastern Pyrenees and related depositional sequences in the southern foreland basin. In: Foreland basins (Ed. by P.A. Allen \& P. Homewood). Spec. Publ. In t. Ass. Sedim., 8, p. 229-246.

Pujadas J., Casas J.M., Muñoz J.A. \& Sàbat F. (1989). - Thrust tectonics and Paleogene syntectonic sedimentation in the Empordà area, southeastern Pyrenees. Geodinamica Acta, 3, $3 \mathrm{p}$.
THomas W.A. (1988). - Stratigraphic framework of the geometry of the basal decollement of the Appalachian-Ouachita fold-thrust belt. Geol. Rundschau, 77/1, p. 183-190.

VERGÉS J. \& MARTÍNEZ A. (1988). - Corte compensado del Pirineo oriental: geometria de las cuencas de antepaís y edades de emplazamiento de los mantos de corrimiento. Acta Geol. Hispànica, 23 (2), p. 95-106.

Manuscrit déposé le 29 octobre 1988 accepté le 28 juin 1989 